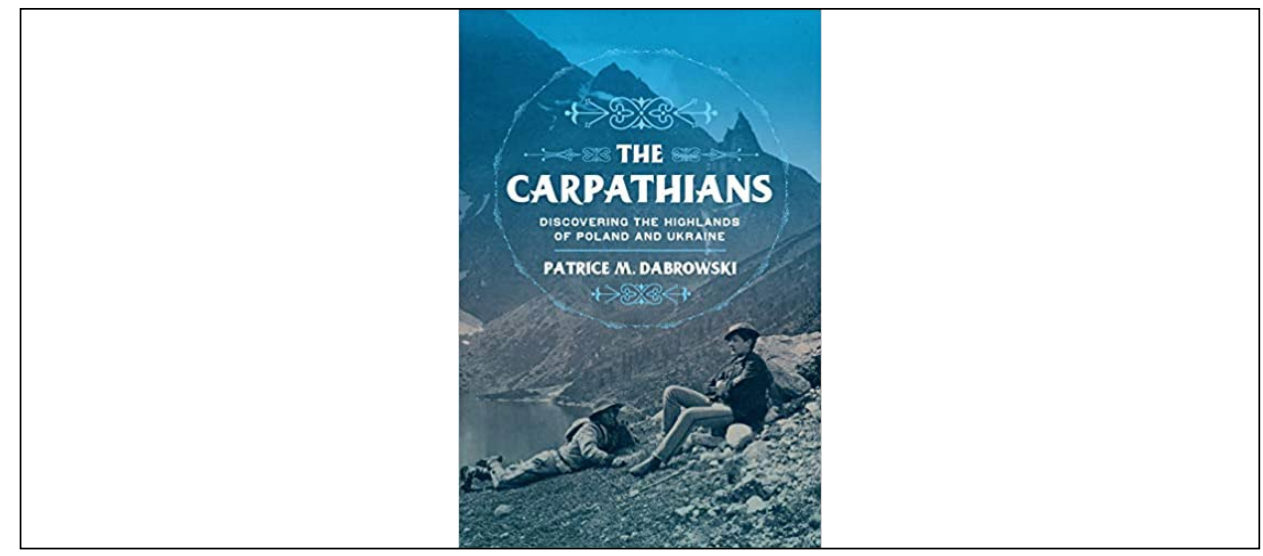

\title{
„Polska Rzeczpospolita Karpacka”
}

https://doi.org/10.19195/2084-4107.15.25

[rec.] Patrice M. Dabrowski, The Carpathians. Discovering the Highlands of Poland and Ukraine, Cornell University Press, Chicago 2021.

\section{The Polish Carpathian Republic}

Słowa-klucze: Karpaty, Tatry, Bieszczady, Czarnohora, mountain studies

Keywords: The Carpathians, The Tatras, Bieszczady Mountains, Chornohora, mountain studies

Góry, ich znaczenie, symbolika i historia poznawania coraz częściej stają się przedmiotem badań kulturowych. Międzynarodowe studia góroznawcze (mountain studies) wykroczyły poza zagadnienia geomorfologii, klimatu czy ochrony przyrody i otworzyły się na nauki humanistyczne i społeczne. W takiej perspektywie opisuje się zarówno te największe i najpopularniejsze pasma oraz łańcuchy, jak i górskie peryferie. Karpaty, nazywane Alpami Europy Wschodniej, stanowią jeden z największych łańcuchów górskich Starego Kontynentu, a ich pasma, rozmieszczone $\mathrm{w}$ granicach wielu państw, są bardzo zróżnicowane — zarówno pod względem krajobrazu naturalnego, jak i kulturowego. Wiele z nich stanowiło scenografię wydarzeń ważnych dla historii różnych narodów - Rumunów, Austriaków, Węgrów, a także Polaków.

Patrice M. Dabrowski w swojej najnowszej książce The Carpathians. Discovering the Highlands of Poland and Ukraine zadaje pytanie: co dla Polaków znaczą góry?, mając na myśli nie tylko popularne Tatry, ale także Bieszczady i, nieprzynależącą już do Polski, Huculszczyznę. Próba odpowiedzenia na to pyta- 
nie została zawarta w szczegółowych omówieniach trzech procesów odkrywania pasm karpackich przez Polaków. Dabrowski, amerykańska badaczka historii Polski, autorka tomu Poland. The First Thousand Years, która w 2014 roku została odznaczona Krzyżem Kawalerskim Orderu Zasługi Rzeczypospolitej Polskiej, w swojej trzeciej monografii przedstawia ponad stuletni proces oswajania gór przez polskie społeczeństwo - od Tatr u schyłku wieku XIX przez Czarnohorę przed i po pierwszej wojnie światowej po Bieszczady drugiej połowy XX stulecia.

Dzieje poznawania i oswajania poszczególnych regionów zostały przez autorkę dokładnie opisane, a następnie zestawione ze sobą w celu jak najgłębszego przeanalizowania ogólnej roli i symboliki gór w polskiej historii. Szczególna uwaga została zwrócona na ich narodotwórczą funkcję oraz wpływ ich odkrycia zarówno na odkrywających, jak i odkrywanych — górali i krajobraz kulturowy.

W swojej książce Dabrowski niejednokrotnie odnosi się do zjawisk i postaci zapomnianych, odsuniętych na boczny tor losów Karpat, książka doskonale wpisuje się więc w popularny obecnie trend re-odkrywania zapomnianego dziedzictwa kulturowego. Dodatkowo umiejscowienie problematyki polskiego krajobrazu w dyskursie międzynarodowym pozwala na spojrzenie na polskie tematy z szerszej perspektywy i dostrzeżenie ponadnarodowych zjawisk. Mimo niezaprzeczalnie wysokiego poziomu naukowego przez publikację przebija osobista fascynacja autorki górami, co tylko wzmacnia całość, a objawia się w specyficznym języku narracji, niejednokrotnie balansującym na granicy poetyzmu.

Badania, których zwieńczeniem jest omawiana monografia, wielokrotnie zaprowadziły badaczkę do Polski i na Ukrainę, zapewniając kontakt z mieszkańcami interesujących ją obszarów górskich i przestrzenią. Rozbudowana sieć współpracy międzynarodowej, zarówno z organizacjami naukowymi (na przykład Pracownia Badań Humanistycznych nad Problematyką Górską), jak i popularyzatorskimi (między innymi Centralny Ośrodek Turystyki Górskiej), przyniosła owoce w postaci dogłębnego poznania polskiej „sprawy górskiej”.

W The Carpathians... Dabrowski wskazuje na istotność Karpat, buduje ich renomę, odnosząc do Alp, a także konstruuje na nowo postrzeganie tych gór. Jednocześnie nie ukrywa ona ich peryferyjnego charakteru oraz znikomej obecności w dyskursie naukowym i międzynarodowej świadomości kulturowej.

Polskie odkrycia, których początek miał miejsce w latach siedemdziesiątych XIX wieku, zostają przedstawione jako powtarzalne zjawisko ściśle związane z sytuacją społeczno-polityczną Polaków i polskiego państwa. Autorka od początku podkreśla rolę regionów górskich w tworzeniu i testowaniu strategii władz. Karpackie peryferie stanowiły pomniejszoną wersję Polski, stawały się więc laboratorium, z którego niejednokrotnie ekstrapolowano regionalne rozwiązania polityczne na resztę kraju.

Tatry, Huculszczyzna i Bieszczady zostały przedstawione w osobnych partiach książki - każdemu regionowi poświęcone zostały cztery rozdziały. Pierwsza część, dotycząca Tatr, w barwny sposób dokumentuje historię stwarzania Zakopanego jako kurortu wysokogórskiego, tłumaczy przyczyny spopularyzowania tej 
miejscowości i wskazuje korzenie obecnego overtourismu. Dabrowski odczarowuje tę tatrzańską miejscowość, przypominając o jej barwnej narodotwórczej historii. Przedstawiając najważniejsze postaci, od Tytusa Chałubińskiego przez Stanisława Witkiewicza po Władysława Zamoyskiego, i wydarzenia związane z rozwojem kurortu, autorka dokumentuje stopniowy rozwój zainteresowania Podtatrzem ze strony turystów i artystów. Zakopane było ważnym miejscem spotkań inteligencji przełomu wieków i jako takie stanowiło arenę kształtowania dyskursu społecznego Polaków pod zaborami. To tam dopracowywano ideę pozytywistyczną, inspirując się góralami i wykorzystując ich wizerunek w celach politycznych. O góralach, ich reakcji na popularyzację Tatr oraz powstaniu i upadku romantycznego mitu górala Dabrowski pisze kompleksowo, wspominając między innymi o nietrafionym sposobie traktowania ludzi gór przez przyjezdnych z nizin. Wprowadzenie cywilizacyjnych wygód i miejskiego stylu życia do pierwotnych wsi góralskich skutkowało naruszeniem spójności góralszczyzny i objawiało się między innymi rosnącą chciwością górali, która wynikała z przepłacania za usługi turystyczno-rozrywkowe.

W rozdziałach dotyczących Tatr Dabrowski wprowadza czytelnika w historię taternictwa, rozpoczynając od wycieczek bez programu dostępnych dla najbogatszych przez wyprawy wspinaczkowe dla młodych pasjonatów o ograniczonym budżecie po turystykę masową uprawianą po dziś dzień.

Drugim regionem, o którym mowa, jest również odkryta przez inteligencję z nizin Huculszczyzna z pasmem Czarnohory. Pierwsze próby skomercjalizowania okolic Kołomyi miały miejsce na początku XX wieku, natomiast działania na dużą skalę z zaangażowaniem jednostek administracji państwowej odbywały się w okresie międzywojennym. Dabrowski zauważa, że duży wpływ na odkrycie Huculszczyzny miało wcześniejsze odkrycie Tatr, a szczególnie powstanie Towarzystwa Tatrzańskiego, które w pierwszych latach XX wieku rozszerzyło swoją działalność właśnie na Karpaty Wschodnie. Z narracji autorki można wnioskować, że co roku zwiększające się rzesze turystów w Tatrach stworzyły potrzebę doświadczenia nowej, mniej zatłoczonej i bardziej dzikiej przestrzeni górskiej. Tatry pod koniec XIX wieku zmieniły swój status z peryferyjnego na centralny, a przez to inne peryferie zostały dostrzeżone $\mathrm{w}$ ich cieniu.

Międzywojenne odkrywanie Czarnohory było rozbudowanym przedsięwzięciem politycznym, co wiązało się ze zmianą tła politycznego — z habsburskiego na nowopolskie. Świadomość multikulturowej tożsamości Hucułów uruchomiła tam ideę ponadnarodowej różnorodności przywodzącą na myśl nie tylko imperium cesarsko-królewskie, ale także Polskę Jagiellonów. Władze II Rzeczypospolitej starały się działać w tym regionie, by, z jednej strony, promować go turystycznie i kulturowo, a z drugiej — umacniać swoje do niego prawo. Organizacje rządowe działające pod płaszczem ruchu społecznego wspierały Hucułów, zachęcały do dzielenia się ich dziedzictwem, a co za tym idzie - starały się utwierdzić ich w przekonaniu, że są Polakami, a nie Ukraińcami. Taka skoncentrowana na peryferiach polityka władz sprzyjała rozwojowi regionalizmu w całej Polsce. 
Zupełnie odwrotną tendencję można dostrzec w opisanej przez Dabrowski historii Bieszczad. Z jednej strony, góry te były związane z Huculszczyzną, bowiem po drugiej wojnie światowej i konferencji jałtańskiej, gdy Polska utraciła Karpaty Wschodnie, Bieszczady jako najdalej na wschód wysunięte pasmo polskich Karpat stanowiły substytut Czarnohory. Podobieństwa dostrzegano w pierwotnej dzikości, ukształtowaniu terenu i malowniczych połoninach. Autorka wyraźnie wskazuje jednak, że zupełnie odmienna była sytuacja społeczno-kulturowa tych ziem. Pustka bieszczadzka spowodowana przesiedleniami i późniejsze starania władz o zasiedlenie tych gór przez przybyszów ze wszystkich krańców Polski sprawiły, że przestrzeń ta nie kojarzyła się z żadnym konkretnym ludem, dziedzictwem czy kulturą. Pozostałości między innymi po Bojkach, Łemkach, Żydach zostały zniszczone, a to, co przetrwało, poddało się działaniu czasu i natury. Odkrywanie Bieszczad w XX wieku, jak zauważa Dabrowski, było procesem wtórnym, spowodowanym zdziczeniem tego kiedyś zaludnionego regionu $\mathrm{z}$ własną tożsamością i historią.

Powojenne losy Bieszczad były burzliwe, a ingerencje w krajobraz naturalny — znaczące. Polityka Polski Ludowej kładła nacisk na monumentalny rozwój zarówno turystyki, jak i przemysłu. Plany stworzenia infrastruktury w regionie zakładały budowę elektrowni, autostrad i bazy noclegowej dla klasy pracującej. Mimo iż o ochronę bieszczadzkiej natury walczyły grupy warszawskich studentów, plany Partii zostały zrealizowane. Część dzikiego pejzażu wypełnił beton, a pośrodku największej dziczy postawiono ogromne tajne hotele dla członków Partii i ważnych gości zza granicy (między innymi w Arłamowie).

Potrzeba kontroli społeczeństwa zaprowadziła władze do ograniczenia wolnego uprawiania turystyki w regionie. Promowano wczasy pracownicze, turystykę zorganizowaną i obozy czy rajdy dla młodzieży przywodzące na myśl przygotowanie wojskowe. Decydowano więc nie tylko o wyglądzie krajobrazu regionu, ale także o sposobach jego doświadczania. Ściśle kontrolowano także napływ ludności, próbując „zachęcać” do przesiedlania się odpowiednich ludzi i „zniechęcać” tych niepożądanych.

Dabrowski, na wzór opisu górali tatrzańskich i Hucułów, sporządziła charakterystykę ludności zamieszkującej Bieszczady w drugiej połowie XX wieku. Pisze między innymi o CHBC, to jest — typowych mieszkańcach tych gór, często uciekających przed obowiązkami czy prawem, wiodących proste życie w lasach. Najbardziej ikonicznym przykładem takiej osoby był niewątpliwie Władysław Nadopta, znany jako Majster Bieda.

Ważnym wątkiem opowieści o Bieszczadach jest zaangażowanie studentów w rozwój i ochronę tego regionu. Szczególnie dużo miejsca poświęcone zostało Studenckiemu Kołu Przewodników Beskidzkich w Warszawie i turystom z Politechniki Warszawskiej, którzy zaangażowali się w spór z władzą o ochronę przyrody Bieszczad.

We wstępie do The Carpathians... jasno określono, że monografia będzie nie tylko dokumentować historię odkrywania części rodzimych Karpat przez 
Polaków, ale także włączać się do dyskusji na temat pozytywnych i negatywnych efektów wprowadzania zurbanizowanej nowoczesności w przestrzenie ruralistyczne. Wielokrotnie został zarysowany konflikt między chęcią ochrony naturalnego krajobrazu i dziedzictwa kulturowego a potencjalnym zyskiem płynącym z ich komercjalizacji. Dostrzegalna jest także powtarzalność „psucia” górali przez przybyszów z nizin. W historii każdego pasma daje się zauważyć, że pierwotność, ,nieodkrytość” gór, z jednej strony, była czynnikiem przyciągającym turystów, z drugiej - stanowiła przeszkodę, której pokonanie, to jest - rozbudowanie infrastruktury turystycznej, miało siłę przyciągnąć tłumy.

Powtarzającym się wątkiem jest rozbieżne traktowanie i pomysły na zagospodarowanie krajobrazu górskiego turystów i władz. Dla działaczy politycznych, czy to w czasie zaborów, czy w II Rzeczypospolitej, czy w PRL, regiony górskie okazywały się istotne dla tworzenia sprzyjającej władzom/inteligencji narracji ideowej. Od szerzenia myśli pozytywistycznych przez umacnianie multietnicznego wizerunku Polski po promowanie wartości komunistycznych — góry stawały się scenografią propagandy. Tatry to Polskie Ateny, miejsce spotkań inteligencji zaangażowanej w sprawę odrodzenia Polski. Czarnohora to europejskie uzdrowisko tworzące wizerunek Polski otwartej, tolerancyjnej i wielokulturowej. Bieszczady to góry dla ludu. Jako takie, wszystkie te pasma odegrały w swoim czasie ważną rolę w kształtowaniu polskości, co tłumaczy, dlaczego góry są tak ważne dla polskiej kultury do dziś. Do popularyzacji gór jako symbolu przyczyniła się sztuka, za pomocą której promowano przestrzenie i ludzi gór. Stanisław Witkiewicz, Stanisław Vincenz i Wadim Berestowski zainspirowani górami tworzyli dzieła, które docierały do szerokiego odbiorcy, przyciągały turystów w opisywane regiony, a obecnie stanowią pamiątkę tego, jak Tatry, Huculszczyznę i Bieszczady postrzegano w czasach ich odkrywania.

The Carpathians... to książka naświetlająca nowe elementy procesów odkrywania gór przez Polaków. Wpisanie wątków regionalnych w ówczesną sytuację społeczno-polityczną narodu polskiego pozwala na odczytanie ich roli w szerszym kontekście i dostrzeżenie istotności przestrzeni górskich w konstruowaniu polskości. Warto też zwrócić uwagę na fakt, że jest to publikacja amerykańska, anglojęzyczna, która ma szanse wzbudzić międzynarodową dyskusję na temat polskich gór oraz stanowić przełomowy impuls w rozwoju rodzimych mountain studies.

Maria Kościelniak

ORCID: 0000-0003-4438-2533

Uniwersytet Wrocławski maria.koscielniak@uwr.edu.pl 